\title{
Demand-led growth and functional income distribution in Brazil from 1952 to 2017
}

Crescimento liderado pela demanda e a distribuição funcional da renda no Brasil de 1952 a 2017

\author{
Joana David Avritzer (1) \\ Fabio Neves Perácio de Freitas (1) \\ Julia De Medeiros Braga (2) \\ (1) Universidade Federal do Rio de Janeiro \\ (2) Universidade Federal Fluminense
}

\section{Abstract}

This work aims to investigate the effect of changes in functional income distribution on growth in Brazil from 1952 to 2017. Following the neo-Kaleckian and Supermultiplier growth and distribution theories, it is possible to obtain two types of such effects. First, a level effect, predicted by both models, establishes a direct relationship of the wage share on the level of output through changes in the components of aggregate demand. Secondly, a growth effect occurs only in the neo-Kaleckian models and is the causal relationship between the wage share and output growth through the rate of capital accumulation. We analyzed the presence of these two effects in the empirical literature and found no evidence of a long run growth regime through capital accumulation as would be expected in the neo-Kaleckian model. However, we find empirical evidence that investment is an induced component of demand as is expected in the Supermultiplier model.

\section{Keywords}

Growth, wage-share, Supermultiplier, neoKaleckian models.

JEL Codes O40, E11, E12, N16.

\section{Resumo}

Este trabalho investiga o efeito de mudanças na distribuição funcional da renda sobre o crescimento no Brasil de 1952 a 2017. Seguindo as teorias de crescimento neo-Kaleckiana e do Supermultiplicador, é possivel obter dois tipos de efeitos. Em primeiro lugar, um efeito nivel, previsto por ambos os modelos, estabelece uma relação direta entre participação dos salários e o produto por meio de mudanças nos componentes da demanda agregada. Em segundo lugar, um efeito crescimento ocorre apenas nos modelos neo-kaleckianos e é a relação causal entre a parcela dos salários e o crescimento do produto por meio da taxa de acumulação de capital. Analisamos a presença desses dois efeitos na literatura empírica e não encontramos evidências de um regime de crescimento de longo prazo, como seria esperado no modelo neo-Kaleckiano. No entanto, encontramos evidências empíricas de que o investimento é um componente induzido da demanda, como é esperado no modelo Supermultiplicador.

\section{Palavras-chave}

Crescimento, distribuição, Supermultiplicador, modelo neo-Kaleckiano.

Códigos JEL O40, E11, E12, N16. 


\section{Introduction}

This paper aims to study the effect of changes in functional income distribution on economic growth in Brazil from 1952 to 2017 from the viewpoint of the Neo-Kaleckian and the Supermultiplier growth models. We investigate two types of effects on the rate of growth of GDP due to changes in functional income distribution according to these models. The first type is the level effect associated with the impact of changes in the wage share on output. Both models predict the existence of this type of effect, which can also be translated into a short run effect on growth, and suggest that they operate by means of the impact of changes in the wage share on the components of aggregate demand. The second type relates to the effect of the wage share on the steady state growth rate, which can only be translated into a long run effect of distribution on the rate of growth of output. Only the neo-Kaleckian growth model predicts the existence of this type of effect. The Supermultiplier model does not predict any systematic long run relationship between functional income distribution and the steady state growth rate of the economy.

In order to address the existence of these effects in the Brazilian economy from 1952 to 2017, this paper is organized as follows. In addition to this introduction and the conclusion, the paper has two sections. The first section summarizes the theoretical work that seeks to understand the relationship between demand-led growth and income distribution, in addition to reviewing the empirical estimations that follow the theories presented. Finally, the second section presents and discusses the results of our empirical investigation of the relationship between growth and distribution in the Brazilian economy in the period under analysis.

It is important to stress here that inasmuch as the purpose of this paper is to differentiate between the empirical results expected in the neo-Kaleckian model from what is expected in the Supermultiplier, we emphasize the difference between a level effect and a growth effect of income distribution on growth. As it becomes clear throughout the theoretical and the empirical review sections, even though the neo-Kaleckian model predicts both a level and a growth effect of distribution on output, the empirical literature that claims to corroborate it only finds short run, level effects. Therefore, our main objective in the empirical work is to differentiate between level, which implies only a short run effect on 
growth, and an actual growth effect, which must impact the steady state rate of growth.

This empirical work also offers an important contribution to the debate on demand-led growth theories by differentiating the expected outcomes in the neo-Kaleckian growth model and in the Supermultiplier model. With that in mind, the empirical work emphasizes this difference between the level and the growth effect, but also focuses on testing the transmission mechanism of income distribution to growth: the capital stock accumulation.

\section{Demand-led growth theories and the functional dis- tribution of income.}

Since their very early contributions, post-Keynesian growth theories aim to extend the principle of effective demand from the short run to the long run, taking into account the effects of changes in income distribution over real output. The purpose of this first section is to highlight the differences between two of these approaches. Subsection 2.1 discusses the neo-Kaleckian model, which is used as a theoretical basis for most of the empirical studies presented in section 2.3. Subsection 2.2 presents the Supermultiplier model as an alternative for studying the relationship between income distribution and growth.

\subsection{Neo-Kaleckian growth models}

In the usual specification of neo-Kaleckian models, capitalist firms operate within an oligopolistic setting and income distribution depends on the determinants of the markup - over unit labor cost - fixed by firms. Following Blecker $(1989 ; 2002)$ and Blecker and Setterfield (2019, chap. 4, sec. 4.4.3), we then consider that in an open-economy the profit share (denoted $\pi$ ) is a function of the desired markup rate of firms reflecting the domestic determinants of the markups (denoted $\mu$ ) and the country's international (unit labor) cost competitiveness position (denoted $z$ ). Thus, we have:

$$
\pi=\pi(\mu, z)
$$


with $\pi_{\mu}>0$ and $\pi_{z}>0$, the signs of the partial derivatives with respect to $\mu$ and $z$ respectively.

Aggregate demand determines the level of output in neo-Kaleckian models. As we will see shortly, capitalist investment is the driving force for economic growth in these models. In the spirit of the original contribution of Bhaduri and Marglin (1990), we specify capitalist investment as a positive function of the profit share and the rate of capacity utilization (denoted $u$ ). That is, we assume that capitalist investment as a proportion of the capital stock $\left(g^{I}\right)$ is given by:

$$
g^{I}=g(\pi, u)
$$

with partial derivatives $g_{\pi}>0$ and $g_{\mu}>0$.

On the other hand, we specify the saving function (saving as a proportion of the stock of capital, $g^{S}$ ) of our neo-Kaleckian model as follows:

$$
g^{S}=\frac{s}{v} u=\frac{1-\left(c_{k}-c_{w}\right) \pi-c_{w}-\eta-b}{v} u
$$

In equation (3), $v$ is the capital to capacity-output ratio, an exogenous variable in the model. The saving (to output) ratio $s$ can be divided into two terms, the domestic and external saving ratio. The domestic saving ratio $1-\left(c_{k}-c_{w}\right) \pi-c_{w}-\eta$ depends on the marginal propensity to consume out of total income (i.e., $\left.\left(c_{k}-c_{w}\right) \pi+c_{w}\right)$ and the government expenditure to output ratio, $\eta$. Adopting the usual practice in neo-Kaleckian models, we assume that ${ }^{1} 0<c_{k}<c_{w}<1$, where $c_{w}$ and $c_{k}$ are, respectively, the marginal propensities to consume out of before-tax wages and profits, which, therefore, include the government tax deductions over wages and profits in their definitions. It follows from this specification and the fact that $0 \leq \pi \leq 1$ that we have $0<\left(c_{k}-c_{w}\right) \pi+c_{w}<1$. For simplicity, we assume that the government expenditure to output ratio is a positive exogenous variable in the present version of the neo-Kaleckian model (i.e., $\eta>0$ ).

In turn, the external saving ratio is captured by the term $-b$, where $b$ is the net exports to output ratio. ${ }^{2}$ Following Blecker (1989 and 2002) and

1 This is the standard assumption of neo-Kaleckian models. See Moreira (2019) for an extension of neo-Kaleckian results when this assumption is abandoned.

2 More precisely, external saving is usually defined as the value of the external current ac- 
Blecker and Setterfield (2019, chap. 4, sec. 4.4.3), we suppose that $b$ depends positively on the level of the real exchange rate, ${ }^{3}$ which is a negative function of the desired markup of capitalist and a positive function of the country's international (unit labor) cost competitiveness position. Hence, we can express the net exports to output ratio as a function of $\mu$ and $z$ :

$$
b=b(\mu, z)
$$

with the partial derivatives $b_{\mu}<0$ and $b_{z}>0$.

In equilibrium, we have the usual condition $g^{S}=g^{I}$. Thus, from equations (1), (2), (3), and (4), we obtain the following equation:

$$
\left(\frac{1-\left(c_{k}-c_{w}\right) \pi(\mu, z)-c_{w}-\eta-b(\mu, z)}{v}\right) u^{*}=g\left(\pi(\mu, z), u^{*}\right)
$$

Observe that given $\mu$ and $z$, both $\pi$ and $b$ are also given, and, therefore, the only endogenous variable remaining in equation (5) is the rate of capacity utilization. Hence, equation (5) determines the equilibrium value of the rate of capacity utilization $u^{*}$, the characteristic neo-Kaleckian closure for the analysis of economic growth and distribution. For this solution to be economically meaningful and stable, the marginal propensity to save out of total income (equal to the saving ratio in neo-Kaleckian models) must be greater than the marginal propensity to invest. That is, we must have $s>v g_{u}$, a Keynesian stability condition. Moreover, simultaneously to the determination of the equilibrium rate of capacity utilization, we obtain the equilibrium value of the rate of output growth of the economy according to the model, that is:

$$
g^{*}=g\left(\pi(\mu, z), u^{*}\right)
$$

count deficit. However, since we are ignoring external net income flows and current net transfers, then the current account deficit coincides with the trade deficit on goods and services.

3 Contrary to Blecker's formulation, however, we will not consider the net exports ratio as a negative function of the rate of capacity utilization. We are already taking care of the influence of the level and growth of economic activity when we express net exports $B$ as a function of the level of output, that is $B=b Y$. This implies that, for a given real exchange rate and, hence, given $b$, exports and imports grow at the same rate as output. 
We may now show the results of the comparative static analysis of the model that is of interest to this paper. The following table presents the partial derivatives of the rate of capacity utilization, and the rate of growth with respect to some of the exogenous variables of the model.

\section{Table 1 Comparative Static Analysis}

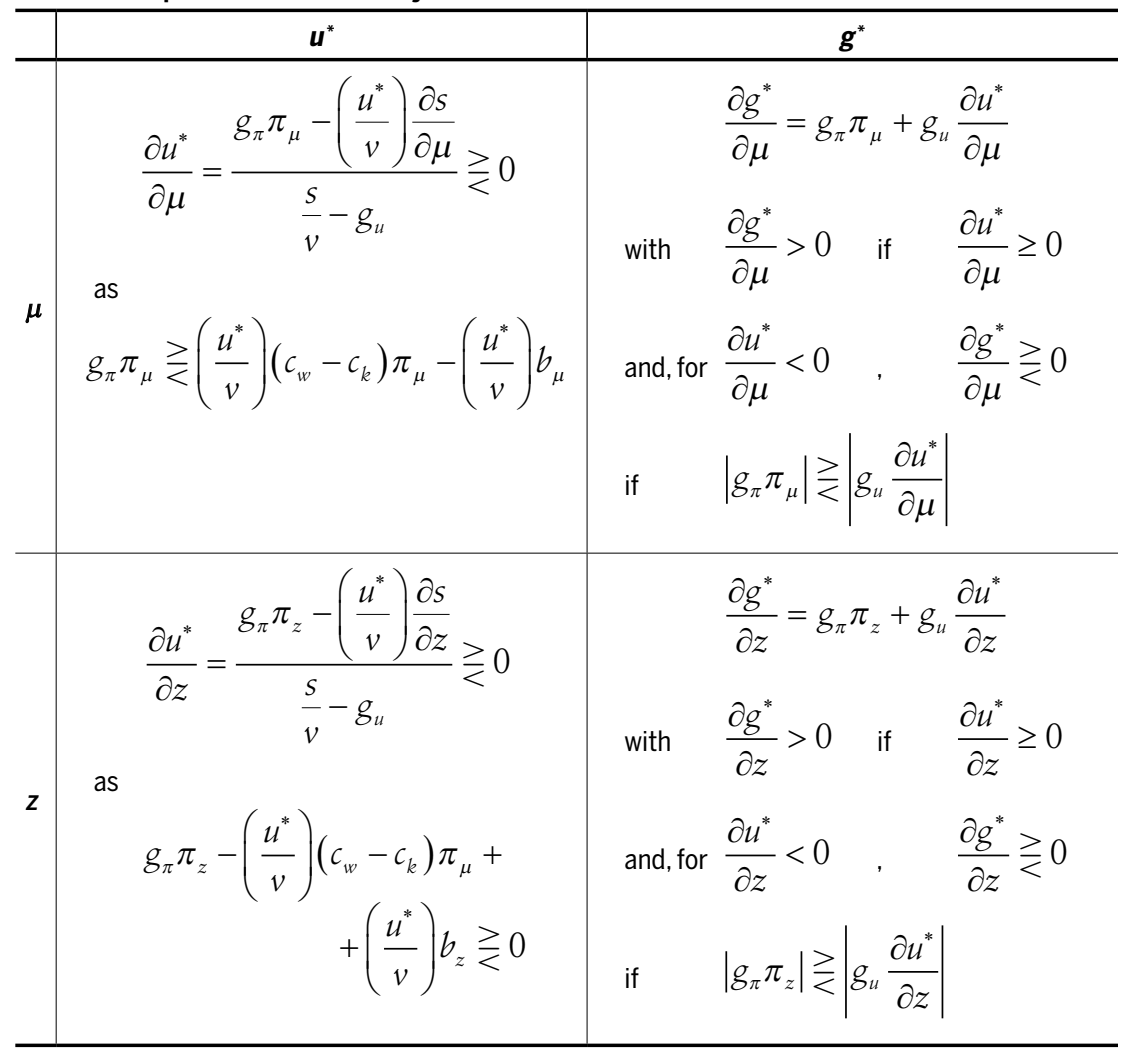

As a first remark, one finds that net investment in equilibrium is given by $I^{*}=g^{*} K$ and, therefore, the equilibrium value of the rate of growth of investment is equal to the rate of capital accumulation. Now, since the level of output $(Y)$ is given by $Y^{*}=I^{*} / s$ and $s$ is exogenously determined, then the investment to output ratio (hereafter investment ratio) is determined by the exogenous saving ratio and, therefore, the rate of investment growth determines the pace of output growth. According to neo-Kaleckian mod- 
els, economic growth is a process led by capitalist investment. For the other aggregate demand components (for instance, consumption, government spending, and net exports) to affect the rate of growth of output, they have to exert their influence through the rate of growth of capitalist investment. Therefore, from the viewpoint of the neo-Kaleckian models, these expenditures are not able to exert a direct and independent influence over the process of economic growth.

A second remark addresses the relationship between aggregate demand, economic growth, and income distribution. In the present version of the model, the profit share depends on the desired markup rate of firms reflecting the domestic determinants of the markup $(\mu)$ and the country's international cost competitiveness position $(z)$. Thus, since $\pi_{\mu}>0$ and $\pi_{z}>0$, a positive (negative) sign of the partial derivative of the rate of capacity utilization and the rate of growth with respect to these variables means the prevalence of a profit-led (wage-led) demand and growth regimes, respectively. In the case of the domestic determinants of the markup, a profit-led (wage-led) demand regime prevails when the impact of its change on investment in one direction is more (less) significant than on the consumption and net exports together in the other direction (note that $\left.b_{\mu}>0\right)$. Further, if the profit-led demand regime holds, then the growth regime is also profit-led. On the other hand, when we have a wage-led demand regime, the growth regime can be either profit-led or wage-led, depending on whether the direct impact of the change of profit share on growth in one direction is, respectively, bigger or smaller than the indirect impact through the rate of capacity utilization in the other direction. Finally, regarding the international cost competitiveness determinant, a profitled (wage-led) demand regime prevails when the impact of its change on investment together with net exports $\left(b_{z}>0\right)$ in one direction is greater (smaller) than its impact on consumption in the other direction. Again, when the profit-led demand regime prevails, then the growth regime is also profit-led. Conversely, if a wage-led demand regime prevails, then the growth regime can be profit-led or wage-led depending on whether the direct impact of the change of profit share on growth in one direction is, respectively, bigger or smaller than the indirect effect through the rate of capacity utilization in the other direction. 


\subsection{A Sraffian Supermultiplier growth model}

The Sraffian Supermultiplier model was proposed by Serrano (1995a; 1995b) as an alternative closure for heterodox growth theory. The main distinctive features of the model are: a) the determination of income distribution along Sraffian lines; b) the treatment of capitalist investment by firms as being induced according to the capital stock adjustment principle; and c) the idea that economic growth is led in the long period by the growth of the autonomous demand components that do not create capacity for the private sector of the economy.

According to Sraffian distribution theory, the wage share depends on the technical conditions of production, on the bargaining power of workers in their negotiations with capitalists, and on how monetary policy is conducted in controlling the long-term rate of interest. As with the neoKaleckian distribution theory, these determinants are, in general, considered to be unrelated in a regular way to the pace of growth of the economy. Hence, they are usually treated as exogenous variables in the basic versions of the Sraffian Supermultiplier models.

As regards the specification of aggregate demand, Supermultiplier models (both Sraffian and Kaleckian ${ }^{4}$ ) divide aggregate demand into induced and autonomous expenditures. Induced expenditures are those that depend in a regular way on current and prospective production decisions of firms governed by the capitalist process of competition. Among these induced expenditures, we have consumption spending financed by the purchasing power (the wage bill) introduced in the economy by production decisions of capitalists firms. In an open economy with government setting and, to simplify our analysis, supposing that all the after-tax wage bill is consumed, we have $C_{w}=\left(1-t_{w}\right) \omega Y$, where $\omega$ is the wage share (with $0<\omega<1$ ) and $t_{w}$ is the tax rate on wages (with $0<t_{w}<1$ ).

As indicated above, the other induced aggregate demand component is investment by capitalist firms. These investment decisions are explained by the capital stock adjustment principle. According to this principle, capitalist competition influences the investment process by bringing about a tendency towards the adjustment of productive capacity to the production flows required to meet demand at a price that covers production expenses 4 Starting with Allain (2015) and Lavoie (2016), there is a growing literature on Kaleckian Supermultiplier models. 
and allows, at least, the obtainment of a minimum required profitability. Since capacity adjustment is not instantaneous due to technical and economic indivisibilities and because firms do not want to lose their market shares to incumbent firms and potential entrants, they maintain margins of planned spare capacity (that corresponds to a normal rate of capacity utilization) to allow the adjustment of production to a fluctuating demand.

To represent this kind of investment behavior, we use the following investment function close to Serrano's original formulation (Serrano 1995a; 1995b), Cesaratto et al. (2003), and, more recently, Serrano et al. (2019): ${ }^{5}$

$$
I=\left(\frac{v}{u_{n}}\right) g^{e} Y
$$

and

$$
\dot{g}^{e}=\gamma\left(g-g^{e}\right)
$$

where $u_{n}$ is the normal rate of capacity utilization (with $0<u_{n}<1$ ), $\frac{v}{u_{n}}$ is the normal capital to output ratio, $g^{e}$ is the expectation of the prospective rate of growth of demand, and $y(>0)$ is the partial adjustment parameter of demand growth expectations to realized growth according to the usual adaptive expectation hypothesis. Note that $\left(\frac{v}{u_{n}}\right) g^{e}$ is the propensity to invest, which is also equal to the investment ratio of capitalist firms. Changes in the investment ratio are essential for the adjustment of capacity to demand. This is the case because the pace of investment governs capacity growth, hence if investment grows faster (slower) than demand and output (i.e., the investment ratio increases (decreases), capacity tends to grow faster (slower) than output causing a reduction (increase) in the actual rate of capacity utilization according to the following differential equation:

$$
\dot{u}=u\left(g-g_{K}\right)=u\left(g-g^{e}\left(\frac{u}{u_{n}}\right)\right)
$$

5 We opted here for this version of the investment function because it is closer to the one used by Serrano et al. (2019) and Braga (2020) for empirical discussions of the Sraffian Supermulplier model. For a different formulation of the investment function, also compatible with the capital stock adjustment principle, see Serrano and Freitas (2017) and Freitas and Serrano (2015). 
where $g_{K}=\left[\frac{\left(\frac{I}{Y}\right)}{v}\right] u=\left[\frac{\left(\frac{v}{u_{n}}\right) g^{e}}{v}\right] u=g^{e}\left(\frac{u}{u_{n}}\right)$ is the rate of capital accumula-
tion.

Autonomous demand components are those demand components not regularly or systematically related to output and output growth. Since we are working in an open-economy setting, autonomous demand components can be divided into domestic demand and exports. Domestic autonomous demand is comprised of consumption financed by credit and government transfers (including capitalist consumption), residential investment, and government expenditures (both consumption and investment). As a simplification, we suppose that these expenditures are exogenously determined.

Furthermore, we assume that exports depend on the total (induced and autonomous) domestic demand of the rest of the world and the ratio of the economy's exports to domestic demand of the rest of the world (hereafter denominated export ratio). We suppose that the latter ratio reflects price and non-price competitiveness of the economy under analysis. Thus, we may represent these assumptions as follows:

$$
Z=A+X=A+\lambda^{R}(\varepsilon, \xi) D^{R}
$$

where $Z$ is total autonomous demand, $A$ is the autonomous domestic demand component, $D^{R}$ is the rest of the world domestic demand and $\lambda^{R}$ is the export ratio (with $0<\lambda^{R}<1$ ), which is a positive function of the real exchange rate $\varepsilon$ (price competition) and of the non-price competitiveness factors $\zeta$ (i.e., we have $\lambda_{\varepsilon}^{R}, \lambda_{\xi}^{R}>0$ ). As can be easily inferred, the rate of growth of total autonomous demand (hereafter denoted $g_{z}$ ) is equal to the weighted average of the growth rates of exports (denoted $g_{A}$ ) and domestic autonomous demand (denoted $g_{X}$ ).

Finally, we have to specify the import function. To simplify, we suppose the economy only imports finished goods, ignoring imports of intermediate goods. In the same spirit, we ignore imports associated with exports (re-exports) and non-competitive imports, and we assume that the import content coefficient is the same for all the domestic demand components (including both induced and autonomous components). The latter coefficient depends negatively on the price (the real exchange rate) and non-price competitiveness factors. Thus, we have: 


$$
M=\lambda(\varepsilon, \xi) D=\lambda(\varepsilon, \xi)\left(\left(1-t_{w}\right) \omega Y+\left(\frac{v}{u_{n}}\right) g^{e} Y+A\right)
$$

where $M$ denotes total imports, $D\left(=C_{w}+I+A\right)$ is total domestic demand and $\lambda=\frac{M}{D}$ the import content coefficient, with $0<\lambda<1$ and $\lambda_{\varepsilon}, \lambda_{\zeta}<0$. $^{6}$

From the equilibrium between aggregate supply $(Y+M)$ and aggregate demand $\left(C_{w}+I+A+X\right)$, we can derive the rate of growth of output outside the steady-state of the model is given by $g$ :

$$
g=\frac{1-(1-\lambda)\left[\left(\left(1-t_{w}\right) \omega+\left(\frac{v}{u_{n}}\right) g^{e}\right) g_{z}-\gamma\left(\frac{v}{u_{n}}\right) g^{e}\right]}{1-(1-\lambda)\left[\left(\left(1-t_{w}\right) \omega+\left(\frac{v}{u_{n}}\right) g^{e}\right)-\gamma\left(\frac{v}{u_{n}}\right)\right]}
$$

From this, we can obtain a dynamical system in $u$ and $g^{e}$ by inserting the equation (12) into the differential equations (8) and (9). ${ }^{7}$ The steady-state solution of this system gives us the following results:

$$
\begin{aligned}
& u^{*}=u_{n} \\
& g_{K}^{*}=g_{I}^{*}=g^{e *}=g^{*}=g_{z} \\
& h^{*}=\left(\frac{v}{u_{n}}\right) g_{z} \\
& \left(\frac{S}{Y}\right)^{*}=\left(\frac{1}{1-\lambda}\right)\left(1-(1-\lambda)\left(1-t_{w}\right) \omega-(1-\sigma \lambda)\left(\frac{Z}{Y}\right)^{*}\right)=h^{*}=\left(\frac{v}{u_{n}}\right) g_{Z} \\
& Y^{*}=\left(\frac{1-\sigma \lambda}{1-(1-\lambda)\left[\left(1-t_{w}\right) \omega+\left(\frac{v}{u_{n}}\right) g_{Z}\right]}\right) Z
\end{aligned}
$$

6 See Miyazawa (1976, chap. 3) for this kind of specification for the import function.

7 For a more detailed analysis of this system see Pariboni (2015). 
where $h$ is marginal propensity to invest (or the investment ratio of capitalist firms), $\sigma=\frac{D}{Z}$ is the share of domestic autonomous demand in total autonomous demand.

The first equation (13) tells us that the steady-state is characterized by the normal utilization of productive capacity. The second one (equation (14)) confirms that the trend rate of growth of output is explained by the rate of growth of total autonomous expenditures that do not create capacity for the private capitalist sector of the economy. Moreover, these expenditures have a direct effect over the trend rate of growth of output, not requiring the mediation through the rate of capacity utilization and the pace of capitalist investment as in the neo-Kaleckian models. In Supermultiplier models they have a growth-determining role in the interpretation of real demandled growth processes, allowing the analysis of export-led, consumptionled, or government (expenditures)-led patterns of economic growth.

The third result expressed in equation (15) is very important and is in fact an intrinsic part of the economic mechanism responsible for the adjustment of capacity to demand connected to the first result commented above. It says that in Supermultiplier models, the investment ratio (more precisely, the investment ratio of capitalist firms) is positively related and caused by the trend rate of growth of output given by $g_{z}$. This feature of the model is supported by robust empirical evidence $e^{8}$ and is not present in neo-Kaleckian models, in which the investment ratio is determined by an exogenous saving ratio.

The fourth result (equation (16)) is also an intrinsic element of the explanation of the tendency of the adjustment of capacity to demand and is the necessary complement to the changes in the investment ratio.. The endogenous determination of the saving ratio with a given income distribution is the distinctive feature of the alternative theoretical closure provided by Supermultiplier models (c.f. Serrano (1995b) and Freitas and Serrano (2015)). In fact, the ability of the model to generate the capacity adjustment with a given income distribution follows from the combination of

8 In this connection, see for instance the evidence found in the literature on growth empirics such as Lipsey and Kravis (1987), De Long and Summers (1991; 1992), Blomström et al. (1996) and Sala-i-Martin (1997). In this respect, see also the empirical analyzes directly connected to the Supermultiplier model such as Girardi and Pariboni (2020) and Braga (2020). 
an investment function based on the capital stock adjustment principle and the existence of autonomous non-capacity creating expenditures that turns the ratio $Z / Y$ (the reciprocal of the Supermultiplier) into an endogenous and adjusting variable.

Finally, the fifth result above (equation (17)) shows the determinants of the equilibrium level of output (equal to the normal level of output) along the steady-state path of the model. The latter depends on the level of total autonomous expenditures and on the equilibrium value of the Supermultiplier. In particular, an increase (a decrease) in the wage share $(\omega)$ provokes an increase (a decrease) in the equilibrium value of the Supermultiplier and, therefore, has a positive (negative) level effect on output after such change happens when compared to the trajectory of output that would have occurred if the change in the wage share did not happen. Using neoKaleckian terminology, the model generates a wage-led demand regime. Notice, however, that the Supermultiplier model does not predict the existence of any regular or systematic relationship between the trend rate of economic growth of the economy and income distribution (c.f., Freitas and Serrano (2015) and Serrano (1995b, chapter 3)).

\subsection{Empirical literature review on growth and distribution}

Since the initial contribution of Bhaduri and Marglin (1990) there have been many attempts to estimate growth regimes of different countries. The papers presented in Table 2 below are selected by Hein (2014) and Blecker (2016) as central papers to the empirical debate on growth and distribution.

Table 2 Neo-Kaleckian empirical results

\begin{tabular}{lll}
\hline Papers & $\begin{array}{l}\text { Author's interpretation } \\
\text { of the results }\end{array}$ & $\begin{array}{l}\text { Interpretation of the result } \\
\text { following Blecker (2002) }\end{array}$ \\
\hline \multirow{3}{*}{ Bowles and Boyer (1995) } & $\begin{array}{l}\text { Demand is profit-led in } \\
3 \text { countries and wage-led } \\
\text { in 2 countries }\end{array}$ & $\begin{array}{l}\text { Demand is profit-led in } \\
3 \text { countries and wage-led } \\
\text { in 2 countries }\end{array}$ \\
\hline \multirow{2}{*}{ Gordon (1995) } & $\begin{array}{l}\text { The result is not interpreted } \\
\text { by the authors in these terms }\end{array}$ & $\begin{array}{l}\text { Not applicable as the derivative } \\
\text { is in terms of the profit rate }\end{array}$ \\
\hline
\end{tabular}

(continues on the next page) 
Table 2 (continuation)

\begin{tabular}{|c|c|c|}
\hline Uemura (2000) & $\begin{array}{l}\text { Growth is profit-led from } 1963 \\
\text { to } 1971 \text { and wage-led from } 1976 \\
\text { to } 1995\end{array}$ & $\begin{array}{l}\text { Demand is profit-led from } 1963 \\
\text { to } 1971 \text { and wage-led from } 1976 \\
\text { to } 1995\end{array}$ \\
\hline $\begin{array}{l}\text { Stockhammer et al. (2009), } \\
\text { Ederer (2008), Stockhammer } \\
\text { and Ederer (2008), } \\
\text { Stockhammer et al. (2011) }\end{array}$ & $\begin{array}{l}\text { Demand is wage-led in three } \\
\text { of the papers and profit-led } \\
\text { for one of the papers }\end{array}$ & $\begin{array}{l}\text { Demand is wage-led in three } \\
\text { of the papers and profit-led } \\
\text { for one of the papers }\end{array}$ \\
\hline $\begin{array}{l}\text { Ederer and Stockhammer } \\
(2007)\end{array}$ & Demand is profit-led & Demand is profit-led \\
\hline Hein and Vogel (2008) & $\begin{array}{l}\text { Growth is profit-led in } \\
2 \text { countries and wage-led } \\
\text { in } 4 \text { countries }\end{array}$ & $\begin{array}{l}\text { Demand is profit-led in } \\
2 \text { countries and wage-led } \\
\text { in } 4 \text { countries }\end{array}$ \\
\hline Hein and Vogel (2009) & $\begin{array}{l}\text { Growth is profit-led in all } \\
\text { economies }\end{array}$ & $\begin{array}{l}\text { Demand is profit-led in all } \\
\text { economies }\end{array}$ \\
\hline $\begin{array}{l}\text { Stockhammer and Stehrer } \\
\text { (2011) }\end{array}$ & $\begin{array}{l}\text { Demand is wage-led in } \\
7 \text { countries }\end{array}$ & $\begin{array}{l}\text { Demand is wage-led in } \\
7 \text { countries }\end{array}$ \\
\hline Onaran and Galanis (2012) & $\begin{array}{l}\text { Demand is wage-led in } \\
9 \text { countries and profit-led in } \\
\text { the remaining } 7 \text { countries }\end{array}$ & $\begin{array}{l}\text { Demand is wage-led in } \\
9 \text { countries and profit-led in } \\
\text { the remaining } 7 \text { countries }\end{array}$ \\
\hline Naastepad and Storm (2007) & $\begin{array}{l}\text { Demand is wage-led in } \\
6 \text { countries and profit-led } \\
\text { in } 2 \text { countries }\end{array}$ & $\begin{array}{l}\text { Demand is wage-led in } \\
6 \text { countries and profit-led } \\
\text { in } 2 \text { countries }\end{array}$ \\
\hline Hartwig (2013) & $\begin{array}{l}\text { The effect of distribution on } \\
\text { growth is profit-led }\end{array}$ & Demand is profit-led \\
\hline $\begin{array}{l}\text { Stockhammer and Onaran } \\
\text { (2004) and Onaran and } \\
\text { Stockhammer (2004) }\end{array}$ & $\begin{array}{l}\text { Distribution is not statistically } \\
\text { significant in explaining growth }\end{array}$ & $\begin{array}{l}\text { Growth regime cannot be } \\
\text { considered profit-led }\end{array}$ \\
\hline Bruno (2003) & Annual data from 1970 to 2001 & $\begin{array}{l}\text { Growth is profit-led from } \\
1970 \text { to } 1990 \text { and wage-led } \\
\text { from } 1991 \text { to } 2001\end{array}$ \\
\hline Araujo and Gala (2012) & Annual data from 2002 to 2008 & Profit-led growth \\
\hline
\end{tabular}

The first three articles presented in Table 2 above may be considered initial empirical exercises that later served as a basis for other neo-Kaleckian works. However, they do not estimate a direct relationship between growth and distribution. Bowles and Boyer (1995), for example, test the relationship between distribution and employment using the excess demand function. 
Following these initial attempts, the neo-Kaleckian empirical literature has developed an extensive debate about the nature of different growth regimes as can be seen in Table 2 above. Blecker (2016) divide these approaches into two categories: a) the structural approach which estimates the final effect of distribution on demand through individual estimations for each component of demand; b) the aggregative approach which estimates this relationship through a "reduced form solution for output" (Blecker, 2016, p. 377). However, as highlighted by Blecker (2016) and many of the authors of the papers above, both approaches estimate the short run, demand effect result and not the growth regime.

Furthermore, it is important to mention that Stockhammer and Onaran (2004) and Onaran and Stockhammer (2004) estimate a relationship between growth and distribution through a system of simultaneous equations. Unlike all the studies mentioned above, these last two papers estimate neo-Kaleckians equations in a simultaneous system and evaluate the final effect of a shock in income distribution on growth by analyzing the impulse response function. In other words, they estimate the final effect of a change in distribution on the rate of growth of output and not only the level effect. The results obtained in Stockhammer and Onaran (2004) and Onaran and Stockhammer (2004) is that a shock in the profit share generates positive effects in the growth rate of capital stock in the United States and France, but not statistically significant ones. This result is the first to approach an actual estimation of a growth regime, but it has only obtained non-significant results.

The neo-Kaleckian empirical literature also tries to estimate the growth regime of the Brazilian economy. Araujo and Gala (2012) and Bruno (2003) estimate equations similar to those proposed by Uemura (2000). However, for these authors, if the derivative of excess aggregate demand concerning the profit share is positive (negative), the growth regime is considered profit-led (wage-led) (Bruno, 2003, p. 6 and Araujo and Gala, 2012, p. 46). Nonetheless, this statement does not correspond to the terminology of Blecker (2002). The signal of the derivative of excess aggregate demand can only indicate the demand regime and not the growth regime, as has already been discussed above. Figure 1 below emphasizes the difference between a level effect (demand regime) and a growth effect (growth regime): 
Figure 1 Growth effect versus level effect

(a) Level (Short-Run) Effect
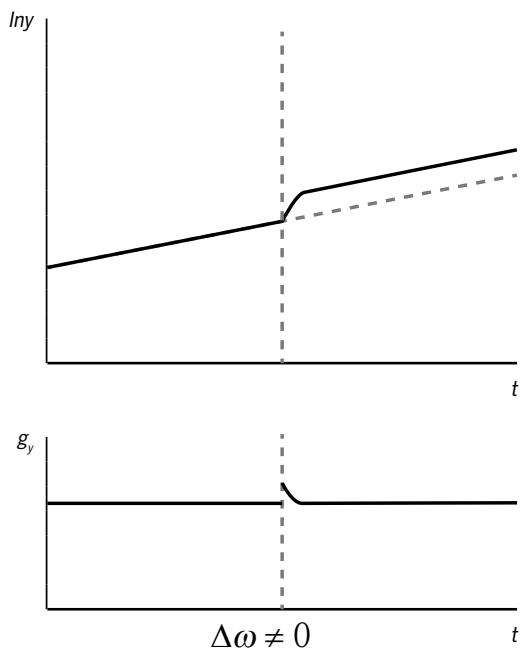

(b) Growth (Long-Run) Effect
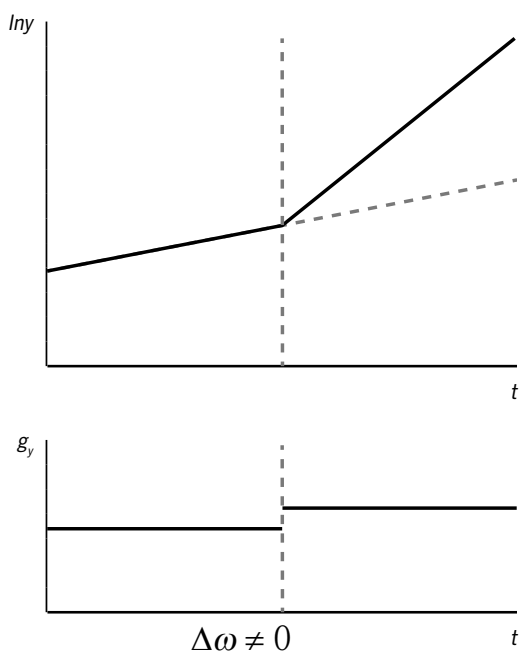

While a level effect causes only a short run outcome on output growth, a growth effect should change the steady state rate of growth of income, which can be translated into a long run effect of income distribution into growth. As mentioned above, while a growth effect is only expected under a neo-Kaleckian model a level effect is an expected outcome of both the neo-Kaleckian and the Supermultiplier model. Furthermore, this growth effect is expected to happen in the neo-Kaleckian model through the rate of capital accumulation and this is why there has been an emphasis on the investment function as the transmission mechanism in the empirical debate.

Finally, it is also important to mention the empirical work pursued by the Supermultplier literature. As argued by Haluska et al. (2020) they can also be divided into two categories. The first group has focused on testing how well autonomous expenditures can explain the level of output. The second group has focused on testing the investment function of the Supermultiplier model, specifically searching for a relationship between the investment to income ratio and the rate of growth of output (Haluska et al, 2020, p. 13). 


\section{Growth and income distribution in Brazil: an empiri- cal study}

This section is an attempt to investigate the empirical relationship between growth and income distribution for the Brazilian economy. With that in mind, this section presents the results of three empirical exercises. The first one focuses on testing for a long run growth effect of income distribution on economic growth. As emphasized in the previous sections, this is an effect that is only expected in the neo-Kaleckian model and its mechanism of transmission happens through the rate of growth of the capital stock. This first empirical exercise then estimates a relationship between the wage-share, the rate of growth of the capital stock and the rate of growth of output through a VAR model. Though a VAR model is not usually associated with estimation of long run behavior, we still considered it to be most appropriate as the growth rates used in this estimation seem to be stationary.

Table 3 Data on growth and distribution

\begin{tabular}{|c|c|c|}
\hline Data & Variable & Source \\
\hline Wage share & $\omega$ & $\begin{array}{r}\text { Marquetti and Porsse (2014) } \\
\text { and SCN-IBGE }\end{array}$ \\
\hline Real Gross Domestic Product & $Y$ & Bacen and SCN-IBGE \\
\hline $\begin{array}{l}\text { Real Investment in Machines } \\
\text { and Equipment }\end{array}$ & l & SCN-IBGE \\
\hline Growth rate of income & $g$ & Growth rate of $Y$ \\
\hline Growth rate of investment & $g_{1}$ & Growth rate of I \\
\hline Share of investment on output & $I / Y$ & $\begin{array}{r}\text { Calculated using data from } \\
\text { Bacen and SCN-IBGE }\end{array}$ \\
\hline
\end{tabular}

The second exercise focuses on estimating the short run, level effect of income distribution on output. For this exercise we used the level of investment and the level of output to study their relationship with income distribution. Since both level series are non-stationary, we decided to estimate the level effect using a cointegration equation. As mentioned throughout the paper, the aim of this empirical investigation is to contribute to the empirical exercises that try to differentiate the expected outcomes of neoKaleckian models from those expected in the Supermultiplier framework. 
We believe an important aspect of this is to differentiate growth effects from level effects of income distribution on capital stock and output.

Finally, the third empirical exercise presents an additional investigation on the investment to income ratio relationship following part of the empirical literature on the Supermultiplier model. In Table 3 we present the data used for this empirical analysis and its sources. All of the data used in this paper are annual data from 1952 to 2017.

Figure 2a Time series used in the empirical work

Time Series Data

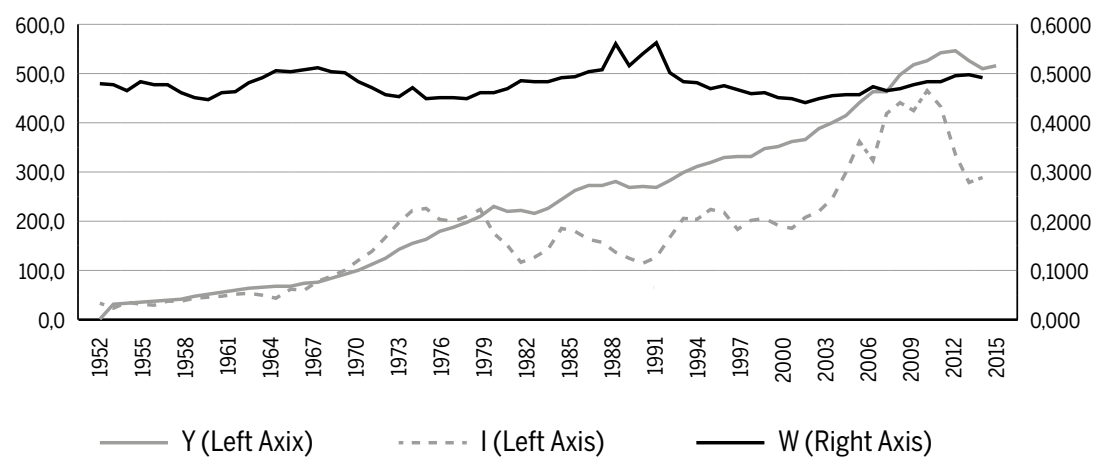

Figure $2 b$ Data Series in Growth and Ratio Terms

Time Series Data

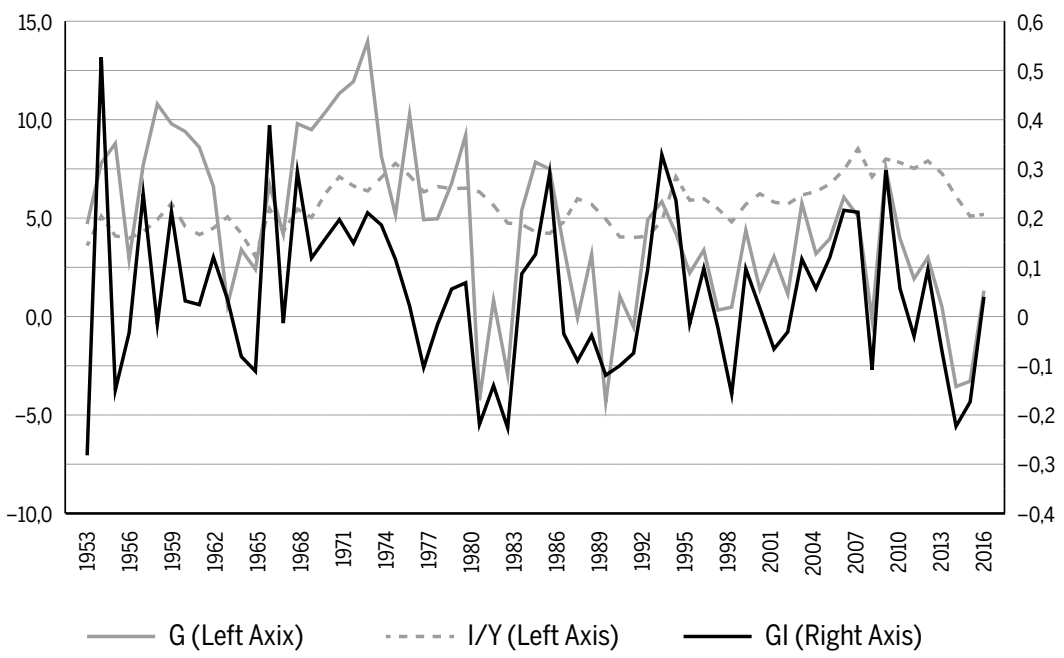


Figure 2 below presents the level data for income, investment and the wage share on the left graph and the data regarding the rate of growth of investment and income, as well as the investment to income ratio on the right graph:

If the series present a non-stationary behavior, it is possible that the econometric regression finds relations between the variables, although there is no causal relationship between them. Thus, Table 4 below begins the empirical work of the estimation of a long run growth effect by presenting the results of the unit root tests for all the data used in the empirical work: a) the level of the wage share; b) the level of investment on machine and equipment; c) the level of income; d) the rate of growth of income; e) the rate of growth of investment; f) the investment to income ratio.

From the test results reported in the table below, we suspect that both the level of income and of investment is non-stationary and that the growth rate of both of them is stationary. These results seem to suggest that both the level of investment and of income are integrated of order one - I(1) processes. Additionally, these first results seem to suggest that the wageshare as well as the investment share on income are stationary time series.

Table 4 Unit root tests ${ }^{9}$

\begin{tabular}{|c|c|c|c|c|c|c|}
\hline $\begin{array}{l}\text { Unit Root } \\
\text { Tests (specifi- } \\
\text { cation: with } \\
\text { intercept } \\
\text { and without } \\
\text { tendency) }\end{array}$ & $\begin{array}{r}\begin{array}{r}\text { Statistics } \\
\text { for the } \\
\text { wage share } \\
(w)\end{array}\end{array}$ & $\begin{array}{r}\text { Statistics } \\
\text { for the level } \\
\text { of income } \\
(Y)\end{array}$ & $\begin{array}{r}\text { Statistics for } \\
\text { the level of } \\
\text { investment } \\
\text { (I) }\end{array}$ & $\begin{array}{r}\text { Statistics } \\
\text { for income } \\
\text { growth } \\
(g)\end{array}$ & $\begin{array}{r}\text { Statistics } \\
\text { for invest- } \\
\text { ment growth } \\
\left(g_{1}\right)\end{array}$ & $\begin{array}{r}\text { Statistics } \\
\text { for the } \\
\text { investment } \\
\text { share on } \\
\text { income } \\
(I / Y)\end{array}$ \\
\hline $\begin{array}{l}\text { ADF } \\
\text { (p-value) }\end{array}$ & $\begin{array}{r}-3.300467^{* *} \\
(0.0193)\end{array}$ & $\begin{array}{r}2.989300 \\
(1.0000)\end{array}$ & $\begin{array}{l}0.35480 \\
(0.9791)\end{array}$ & $\begin{array}{r}-4.396086^{* * *} \\
(0.0008)\end{array}$ & $\begin{array}{r}-8.186934^{* * *} \\
(0.0000)\end{array}$ & $\begin{array}{r}-2.594725^{*} \\
(0.0992)\end{array}$ \\
\hline $\begin{array}{l}\text { PP } \\
\text { (p-value) }\end{array}$ & $\begin{array}{r}-2.737653^{*} \\
(0.0735)\end{array}$ & $\begin{array}{r}2.521890 \\
(1.0000)\end{array}$ & $\begin{array}{r}0.096970 \\
(0.9630)\end{array}$ & $\begin{array}{r}-4.373835^{* * * *} \\
(0.0008)\end{array}$ & $\begin{array}{r}-8.170031^{* * *} \\
(0.0000)\end{array}$ & $\begin{array}{r}-2.594725^{*} \\
(0.0992)\end{array}$ \\
\hline KPSS & 0.082849 & $0.991346^{* * *}$ & $0.804409 * * *$ & $0.582210^{* *}$ & 0.097305 & $0.398101^{*}$ \\
\hline ERS & $0.363177^{* *}$ & 861.7429 & 45.33912 & $1.497782^{* * *}$ & $2.866381^{* *}$ & 4.415469 \\
\hline DF-GLS & $-3.332607^{* * *}$ & 1.164959 & 1.150849 & $-2.714308^{* * *}$ & $-2.479604 * * *$ & $-2.030270^{* *}$ \\
\hline \multicolumn{7}{|l|}{ Ng-Perron tests } \\
\hline Mza & $-69.9781^{* * *}$ & 2.13466 & 2.25542 & $-12.7277^{* *}$ & $-6.97326^{*}$ & $-7.19300^{*}$ \\
\hline MZt & $-5.90683^{* * *}$ & 1.77952 & 1.32339 & $-2.43880^{* *}$ & $-1.86436^{*}$ & $-1.89337^{*}$ \\
\hline MPT & $0.36850^{* * *}$ & 61.3800 & 34.4576 & $2.24949 * *$ & $3.52386^{*}$ & $3.41740^{*}$ \\
\hline
\end{tabular}

9 Notes: ${ }^{*}$ Significance level is $10 \%$; ${ }^{* *}$ Significance level is $5 \%$; ${ }^{* * *}$ Significance level is $1 \%$. 
However, given the behavior of the wage-share presented in the graphs of figure 1 above, we decided to run additional tests for unit root with structural break. We present the test results for the wage-share, the levels and the growth rates of income and investment and for the investment to income ratio in Table 5 below:

Table 5 Results of unit root tests with structural breaks for all series ${ }^{10}$

\begin{tabular}{lrrrrrrr}
\hline & $\boldsymbol{\omega}$ & $\boldsymbol{Y}$ & $\boldsymbol{I}$ & $\boldsymbol{g}$ & $\boldsymbol{g}_{\boldsymbol{I}}$ & $\boldsymbol{I / Y}$ \\
\hline Test ZA statistic & -3.513785 & -3.75314 & -3.443439 & $-5.568656^{* * *}$ & $-6.268119^{* * *}$ & -3.499785 \\
\hline $\begin{array}{l}\text { Structural Break } \\
\text { Date for ZA }\end{array}$ & 1994 & 2005 & 1980 & 1980 & 1975 & 1981 \\
\hline $\begin{array}{l}\text { Test LS statistic } \\
\text { Structural Break }\end{array}$ & -4.895317 & $-5.506419^{*}$ & $-5.462867^{*}$ & $-5.534329^{* * *}$ & $-6.467034^{* * *}$ & -5.075082 \\
\hline $\begin{array}{l}\text { Date for LS } \\
\text { and 1992 }\end{array}$ & $\begin{array}{r}1983 \\
\text { and 1991 }\end{array}$ & $\begin{array}{r}1979 \\
\text { and 2008 }\end{array}$ & $\begin{array}{r}1967 \\
\text { and 1974 }\end{array}$ & $\begin{array}{r}1974 \\
\text { and 2004 }\end{array}$ & $\begin{array}{r}1975 \\
\text { and 2004 }\end{array}$ \\
\hline
\end{tabular}

The above tests cannot reject the null hypothesis of the presence of unit root with a structural break at $1 \%$ level of confidence for almost all of the used time series, except for the growth rate of income and of investment. It is important to emphasize that in the presence of structural break, the usual unit root tests are biased for non-rejection of the unit root hypothesis. The unit root tests for the wage share presented in Table 4 pointed to the rejection of the null hypothesis of a unit root. However, when the possibility of a structural break is allowed for, the distributive variable seems to be integrated with two structural breaks, one in the 1970s and another in the mid-1990s. This result seems to be confirmed by the analysis presented in Figure 1 at the beginning of this section.

\subsection{Long run effect estimation}

Since the results were slightly ambiguous about the stationarity of the wage-share, we decided to run a VAR for the relationship between the wage-share and the growth of income and of investment. The main reason is that it is unambiguous that both rates of growth are stationary so

10 Notes: * Significance level is $10 \%$; ${ }^{* *}$ Significance level is $5 \%$; ${ }^{* * *}$ Significance level is $1 \%$. 
we are not running the risk of estimating a spurious regression between independent and integrated variables even if the wage-share is not stationary. Additionally, we can also check the stability of the estimated VAR through the roots of the AR characteristic polynomial.

While the Akaike, Schwarz and Hanna-Quin information criterias point to a VAR with one lag, VAR (1), the likelihood ratio test points to three lags, VAR (3). In addition to the information criteria, we also looked at the autoregressive behavior of each series individually and found that the rate of growth of income has an autoregressive behavior of order 2 while the wage-share has an autoregressive behavior of order 4. In order to choose the best model, the residuals tests of three VAR specifications - VAR (1), VAR(3) and VAR(4) - are reported in Table 6 below. All of the VAR models for the growth effect were estimated with one time dummy in 1994, because of the structural break test for the wage share, and another time dummy in 1981, because of the AR(2) behavior of the rate of growth of income, which presented an outlier in 1981.

Table 6 Residual tests for VAR (1), VAR (3) and VAR (4) for the growth effect ${ }^{11}$

\begin{tabular}{lrrr}
\hline & VAR (1) & VAR (3) & VAR (4) \\
\hline \multirow{2}{*}{ Tests } & $\begin{array}{r}\text { Statistics } \\
(\mathrm{p} \text {-value) }\end{array}$ & $\begin{array}{r}\text { Statistics } \\
(\mathrm{p} \text {-value) }\end{array}$ & $\begin{array}{r}\text { Statistics } \\
(\mathrm{p} \text {-value) }\end{array}$ \\
\hline \multirow{2}{*}{ Autocorrelation LM Test: LRE stat } & 74.55190 & 78.54872 & 77.79106 \\
& $(0.3953)$ & $(0.2792)$ & $(0.2996)$ \\
\hline \multirow{2}{*}{ Autocorrelation LM Test: Rao F-stat } & 1.022435 & 1.084034 & 1.057403 \\
& $(0.4557)$ & $(0.3361)$ & $(0.4136)$ \\
\hline \multirow{2}{*}{ Jarque-Bera } & $50.06742^{* * *}$ & $24.92470^{* * *}$ & $33.07934^{* * *}$ \\
& $(0.0000)$ & $(0.0004)$ & $(0.0000)$ \\
\hline \multirow{2}{*}{ Kurtosis } & $42.46689^{* * *}$ & $21.05196^{* * *}$ & $25.81562^{* * *}$ \\
& $(0.0000)$ & $(0.0001)$ & $(0.0000)$ \\
\hline \multirow{2}{*}{ Skewness } & $7.600534^{*}$ & 3.872747 & $7.263718^{*}$ \\
\hline \multirow{2}{*}{ Test for Heteroscedasticity } & $(0.0550)$ & $(0.2755)$ & $(0.0640)$ \\
\hline
\end{tabular}

11 Notes: * Significance level is $10 \%$; ${ }^{* *}$ Significance level is $5 \%$; ${ }^{* * *}$ Significance level is $1 \%$. 
From the tests reported in the table above a VAR (4) seems to be the most adequate specification, since it does not reject the null hypothesis of homoscedasticity. Additionally, the inverse roots of the AR characteristic polynomial were all inside the unit circle, indicating that the estimated VAR (4) is stationary.

Furthermore, in Table 7 below we report the Granger causality test for all series. In the results below we can only reject the null hypothesis that economic growth does not Granger cause investment growth. This result is more compatible with the Supermultiplier model that assumes that investment is endogenous to output. The wage share does not seem to Granger cause the growth rate of the economy or investment. Therefore, this test does not corroborate the result predicted in the neo-Kaleckian model à la Bhaduri and Marglin (1990).

Table 7 Granger Causality Test for growth effects

\begin{tabular}{lr}
\hline Null Hypothesis & $\begin{array}{r}\text { Statistic } \\
(\mathbf{p} \text {-value) }\end{array}$ \\
\hline g does not Granger-Cause $g_{l}$ & $\begin{array}{r}16.05839 \\
(0.0029)\end{array}$ \\
\hline \multirow{2}{*}{ does not Granger-Cause $g$} & 3.251639 \\
& $(0.5166)$ \\
\hline \multirow{2}{*}{ does not Granger-Cause $g_{l}$} & 0.741009 \\
& $(0.8635)$ \\
\hline g does not Granger-Cause $\omega$ & 0.918844 \\
\hline \multirow{2}{*}{$\omega$ does not Granger-Cause $g$} & $(0.9218)$ \\
\hline \multirow{2}{*}{ does not Granger-Cause $\omega$} & 2.876055 \\
& $(0.5788)$ \\
\hline
\end{tabular}

In the decomposition of the variance ${ }^{12}$, the wage share appears with a low percentage (below 10\%) of explanation for variations in the growth rate of investment. Additionally, from Figure 3 below, we find that the impulse

12 The chosen Cholesky ordering for the variance decomposition as well as the impulse response function took the wage share as the most exogenous variable and the rate of growth of investment as the most endogenous variable of the model. This ordering was chosen taking into account the results of the Granger Causality tests. 
response functions of the effects on $g_{I}$ of a shock on $\omega$ are estimated negative, but not significant. This result, as well as the Granger causality test, does not corroborate the neo-Kaleckian model, since variations in the wage share have little effect on changes in the rate of growth of investment.

Furthermore, we also see that the effect on $g$ of a shock on $\omega$ is negative and statistically significant for the first period after the shock on $\omega$. This result seems at first to be an empirical evidence of a growth regime as suggested by neo-Kaleckian models, however, the transmission mechanism is not happening through investment growth as would be expected in this model.

Figure 3 Impulse Response Function for the VAR (3) of the growth effect estimation ${ }^{13}$

(a) Response of W to W

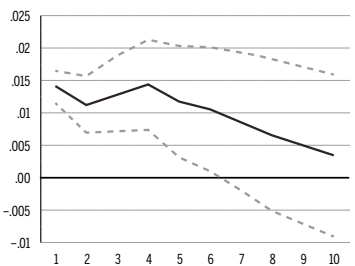

(d) Response of G to W

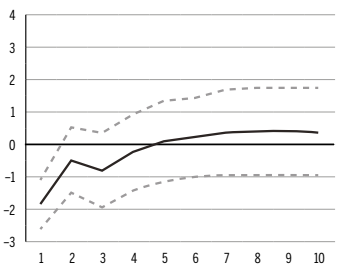

(g) Response of GI to W

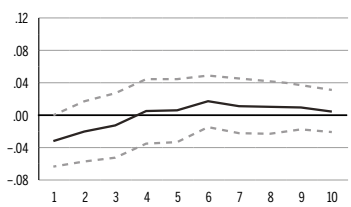

(b) Response of W to $G$

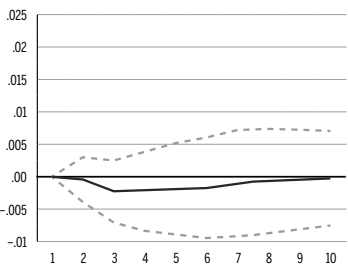

(e) Response of G to G

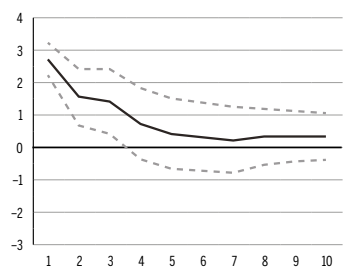

(h) Response of GI to G

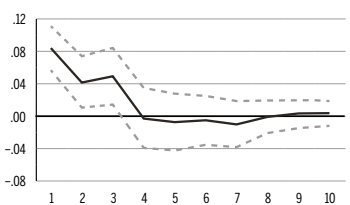

(c) Response of W to GI

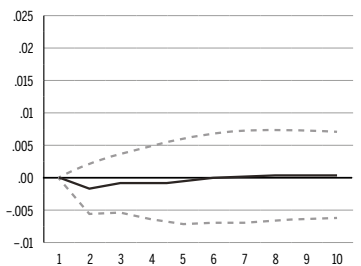

(f) Response of G to GI

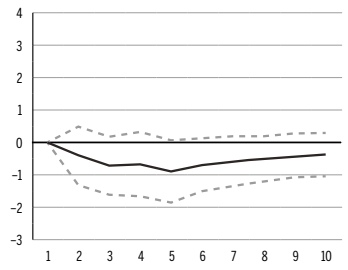

(i) Response of GI to GI

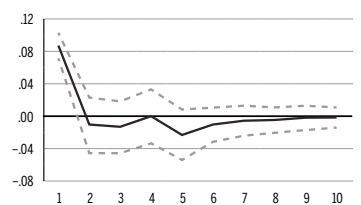

Finally, the only null hypothesis that has been rejected was that $g$ did not Granger-Cause $g_{I}$. In Figure 3 below, the effect of a shock of the growth rate of the economy on the rate of growth of investment is positive and significant for the consecutive three periods. Thus, from the impulse re13 In Figure 3 GI is the growth rate of investment, GY is the growth rate of income and W is the level of the wage share. 
sponse function we also find that a shock on the rate of growth of output has a positive effect on the growth rate of investment, which corroborates again the hypothesis of endogenous investment growth under steady state adopted in the Supermultiplier model. ${ }^{14}$

\subsection{Short run effect estimation}

As previously discussed, the estimation of a short run effect of the wage share is different from estimating a neo-Kaleckian growth regime. This type of effect, in fact, is predicted by both the neo-Kaleckian models and the Supermultiplier model. We estimate the relationship between the level of the variables under analysis using a cointegration model adding the possibility of a structural break in the variables. Since the wage share can be considered integrated with a structural break and both the level of investment as well as the level of income are unambiguously integrated, cointegration tests with structural break are reported in Table 8 below.

Table 8 Cointegration test LST with structural break ${ }^{15}$

\begin{tabular}{lcrr}
\hline Null Hypothesis/ Test Statistics & $r<1$ & 8.66 \\
\hline Structural Break Date & $r=0$ & $25.63^{* *}$ \\
\hline & 1995 & \\
\hline
\end{tabular}

We chose the Lütkepohl, Saikkonen and Trenkler test, which does not need the hypothesis of exogeneity of the variables since it estimates the cointegration relation based on a system of autoregressive vectors. By the LST test, we reject the null hypothesis of $r=0$ for the level effect. However, we do not reject the null hypothesis of $r \leq 1$, that is, that there is at least one cointegrating vector. Therefore, in general, it seems reasonable to assume that the level series are cointegrated, possibly with a structural break in the mid-1990s.

14 We also looked at the aggregated impulse response function for this VAR, but decided not to report it here as the results are not significantly different from the impulse response function already presented in the paper.

15 Notes: * Significance level is $10 \%$; ** Significance level is $5 \%$; *** Significance level is $1 \%$;; For the GH test the model was estimated with no trend because when the trend was included it was not significant. 
Additionally, Table 9 reports the cointegration tests that were done for every two variables. With this, we aim to better evaluate the relationship of structural cointegration between the variables of the model.

Table 9 Coefficient Estimation of the GH test ${ }^{16}$

\begin{tabular}{|c|c|c|c|c|c|}
\hline $\begin{array}{l}\text { Dependent } \\
\text { Variable: } Y\end{array}$ & $\begin{array}{r}\text { Estimated } \\
\text { Coefficient } \\
(t \text { Statistics })\end{array}$ & $\begin{array}{l}\text { Dependent } \\
\text { Variable: } Y\end{array}$ & $\begin{array}{r}\text { Estimated } \\
\text { Coefficient } \\
\text { (t Statistics) }\end{array}$ & \begin{tabular}{|c|} 
Dependent \\
Variable: I
\end{tabular} & $\begin{array}{r}\text { Estimated } \\
\text { Coefficient } \\
\text { (t Statistics) }\end{array}$ \\
\hline Intercept & $\begin{array}{r}253.86226^{* * *} \\
(3.009112)\end{array}$ & Intercept & $\begin{array}{r}12.6169137^{* * * *} \\
(3.763109)\end{array}$ & Intercept & $\begin{array}{r}459.353237^{* *} \\
(2.140962)\end{array}$ \\
\hline$\omega$ & $\begin{array}{r}-550.658877^{* * *} \\
(-3.123037)\end{array}$ & I & $\begin{array}{r}0.4861123^{* * * *} \\
(9.141782)\end{array}$ & $\omega$ & $\begin{array}{r}-982.394897^{* *} \\
(-2.210380)\end{array}$ \\
\hline$D_{1986}$ & $\begin{array}{r}-367.992946^{* * *} \\
(-3.450555)\end{array}$ & $D_{1977}$ & $\begin{array}{r}56.3694936 \text { **** } \\
(5.346747)\end{array}$ & $D_{1982}$ & $\begin{array}{r}-513.056733^{*} \\
(-1.992203)\end{array}$ \\
\hline Trend & $\begin{array}{l}7.049550^{* * *} \\
(21.634288)\end{array}$ & Trend & $\begin{array}{r}2.1763084^{* * *} \\
(4.794293)\end{array}$ & Trend & $\begin{array}{r}6.708186 * * * \\
(6.970278)\end{array}$ \\
\hline$D_{\text {Trend }}$ & $\begin{array}{r}3.651556^{* * *} \\
(6.691218)\end{array}$ & $D_{\text {Trend }}$ & $\begin{array}{r}4.7109776 * * * \\
(9.746213)\end{array}$ & $D_{\text {Trend }}$ & $\begin{array}{r}1.501280 \\
(1.170849)\end{array}$ \\
\hline$D_{1986}^{*} \omega$ & $\begin{array}{r}722.821423^{* * * *} \\
(3.297093)\end{array}$ & $D_{1977}^{*} I$ & $\begin{array}{r}-0.1238535^{* *} \\
(-2.182400)\end{array}$ & $D_{1982}^{*} \omega$ & $\begin{array}{r}846.321474 \\
(1.574800)\end{array}$ \\
\hline $\begin{array}{l}\text { GH test } \\
\text { statistics }\end{array}$ & -3.303448 & & -3.104475 & & -4.530575 \\
\hline
\end{tabular}

First, all the statistics of the Gregory and Hansen (1996) tests cannot reject the null hypothesis, not even at the $10 \%$ confidence level, of non-cointegration of the variables when taken two by two. However, it is worth remembering that this test presupposes the exogeneity of the explanatory variable, which can hardly be assumed in any of the three cases.

Secondly, the coefficient of wage share in the equation that explains output is estimated negative and significant before 1986 and positive and significant after 1986. Also, the coefficient of the distributive variable was estimated with a magnitude significantly higher after 1986 . The estimated outcome for the relationship between output and distribution is not very favorable to the short run effect proposed a priori by the Supermultiplier models - in the model presented for a closed economy - but in the neo16 Notes: * Significance level is $10 \%$; ${ }^{* *}$ Significance level is $5 \%$; ${ }^{* * *}$ Significance level is $1 \%$; D_X denotes a dummy variable of the structural break at time X. 
Kaleckian model which allows for regime change. However, the analysis of these results should take into account that the data used for the wage share were estimated by Marquetti and Porsse (2014) because data can only be obtained directly from the System of National Accounts from 1995 onwards. The data of Marquetti and Porsse (2014) was used in this paper because otherwise the database would be reduced to a sample of only sixteen years. Nonetheless, it is necessary to recognize the limitation of the data used in this estimation. ${ }^{17}$

Finally, the distributive variable has a similar behavior in both the equation that explains the investment and the equation that explains output. The results obtained here seem to corroborate to some extent the models that allow a variation in the demand regime of an economy. However, it is worth noting that the estimated parameter for the wage share in the investment equation is always lower in absolute terms than it is in the output equation. This points to the importance of the other components of demand, consumption, exports and government expenditures, for the explanation of the relationship between output and the wage share. ${ }^{18}$

As a final empirical exercise, we decided to also run a specific test for the Supermultiplier model. Towards that end, in the following section we add further empirical work on the investment to output ratio.

\subsection{Further estimations with the investment to income ratio}

In order to better test for the Supermultiplier model, we decided to look further into the behavior of the investment function by testing the variables that explain the investment to output ratio. Since the unit root tests were ambiguous about the stationarity of both the wage-share and the investment to income ratio, but unambiguous about the stationarity of the rate of growth of income, we decided to estimate the relationship between these variables assuming a stationary system, but controlling for outliers

17 For example, in the 1980s the wage share presents a strong growth in this data. This increase can be justified by the stagnation of labor productivity. However, in this period, the real wage grows very little, which hinders the possibility the wage share has grown in the magnitude estimated in Marquetti and Porsse (2014).

18 Several other specifications of this relationship were also estimated, for example, incorporating Markov Switching and BREAKLS. However, we did not obtain significant additional results for this work and so we chose not to report them in the article. 
through a time dummy variable. Table 10 below reports the Granger Causality test for the three variables used in this estimation.

Table 10 Granger Causality tests for the Investment to Output Ratio

\begin{tabular}{|c|c|}
\hline Null Hypothesis & $\begin{array}{l}\text { Statistic } \\
\text { (p-value) }\end{array}$ \\
\hline$g$ does not Granger-Cause $I / Y$ & $\begin{array}{l}2.83696 \\
(0.0142)\end{array}$ \\
\hline$I / Y$ does not Granger-Cause $g$ & $\begin{array}{l}0.80638 \\
(0.6011)\end{array}$ \\
\hline$\omega$ does not Granger-Cause $I / Y$ & $\begin{array}{r}1.11130 \\
(0.3776)\end{array}$ \\
\hline$I / Y$ does not Granger-Cause $\omega$ & $\begin{array}{r}0.75711 \\
(0.6417)\end{array}$ \\
\hline$\omega$ does not Granger-Cause $g$ & $\begin{array}{c}0.86972 \\
(0.5494)\end{array}$ \\
\hline$g$ does not Granger-Cause $\omega$ & $\begin{array}{l}1.04241 \\
(0.4211)\end{array}$ \\
\hline
\end{tabular}

From Table 10 above we see that only the null hypothesis that the rate of growth of income does not granger cause the investment to output ratio is rejected. Therefore, we can estimate a relationship between the three variables - the rate of growth of income, the wage share and the investment to output ratio - using a least square single equation estimation that assumes both the wage-share and the investment ratio are exogenous variables. Table 13 below reports the results for the estimated equation of the investment to output ratio $I / Y$ as a function of the rate of growth of the economy as well as the wage share.

The results of table 11 above show that while the rate of growth of income is significant in explaining the behavior of the investment to income ratio, the wage share is non-significant. Additionally, we do not reject the null hypothesis of no autocorrelation and no heteroskedasticity in the error term. This is a result that is more consistent with the expected dynamics under a Supermultiplier model. 
Table 11 Results of the least square estimation for the Investment to Income Ratio ${ }^{19}$

Dependent Variable: $I / Y$

Estimated Coefficient

(t Statistics)

Intercept

3.053846

(1.315583)

$0.043124^{*}$

$g$

(1.708168)

$(I / Y)_{t-1}$

$0.784985^{* * *}$

$(9.455613)$

$2.068298 * * *$

$D_{1995}$

(2.793065)

$\omega$

$-4.250739$

$(-1.003711)$

\begin{tabular}{lr}
\hline Breusch-Godfrey Serial Correlation LM Test & 0.952157 \\
\hline Breusch-Pagan-Godfrey Heteroskedasticity Test & 0.545550 \\
\hline ARCH Heteroskedasticity Test & 2.641954 \\
\hline
\end{tabular}

\section{Conclusion}

Our empirical analysis has produced important results that are worth emphasizing at this point. First, we have found that, given the granger causality tests, as well as the impulse response function and the variance decomposition of the VAR estimated for the long-run empirical work, the rate of growth of output is significant in explaining the behavior of the rate of growth of capital accumulation. This result is consistent with what is expected in the Supermultiplier model as emphasized in the theoretical section, since it is suggesting that investment is an induced component of demand. This first result is further corroborated by the estimations done with the investment to output ratio, which also suggest that the rate of growth of the economy is relevant in explaining the investment to output ratio.

Second, the impulse response function of the VAR estimated for the long-run regime has shown that while the wage-share seems to have a negative effect on the rate of growth of the economy, this effect does not happen through the investment function since the wage share does not

19 Notes: * Significance level is $10 \%$; ${ }^{* *}$ Significance level is $5 \%$; ${ }^{* * *}$ Significance level is $1 \%$. 
have a significant effect on the rate of growth of capital accumulation. Therefore, while at first this result seems to be suggesting a profit-led growth regime for Brazil, this regime cannot be explained by the neo-Kaleckian growth model, since the transmission mechanism is not the investment function as would be required in a neo-Kaleckian model a la Bhaduri and Marglin (1990).

Finally, a third interesting result of the empirical work is that the income distribution variable seems to have a level (short-run) effect on both the investment and output. However, as emphasized in the theoretical section, this demand effect is expected on both the Supermultiplier and the neoKaleckian models of growth. In conclusion, by emphasizing the theoretical differences between the two growth models, we have found empirical evidence in the Brazilian economy that corroborates some of the expected outcomes and relationship of the Supermultiplier model. First, we found evidence that the wage-share only affects short-run demand, but not the rate of capital accumulation. Second, we have found significant evidence for claiming the investment is actually induced by economic output.

\section{References}

ALLAIN, O. Tackling the instability of growth: a Kaleckian-Harrodian model with an autonomous expenditure component. Cambridge Journal of Economics, v. 39, n. 5, p. 1351-71, 2015.

ARAUJO, E.; GALA, P. Regimes de crescimento econômico no Brasil: evidências empíricas e implicações políticas. Estudos Avançados, v. 26, 2012.

BHADURI, A.; MARGLIN, S. Profit Squeeze and Keynesian Theory. In: MARGLIN, S.; SCHOR, J. (eds.) The Golden Age of Capitalism: Reinterpreting the Postwar Experience, Oxford, Clarendon Press, 1990.

BLECKER, R. International competition, income distribution and economic growth, Cambridge Journal of Economics, v. 13, n. 3, p. 395-412, 1989.

BLECKER, R. Distribution, Demand and Growth in neo-Kaleckian Macro Models. In: Setterfield, M. (ed.) The Economics of Demand-Led Growth: Challenging the Supply-side Vision of the Long Run, Aldershot, Edward Elgar, 2002.

BLECKER, R. Wage-led versus profit-led demand regimes: the long and the short of it. Review of Keynesian Economics, v. 44, p. 373-390, 2016.

BLECKER, R.; SETTERFIELD, M. Heterodox Macroeconomics: Models of Demand, Distribution and Growth, Cheltenham, UK, Edward Elgar, 2019.

BLOMSTRÖM, M.; LIPSEY, R.; ZEJAN, M. Is fixed investment the key to economic growth?, Quarterly Journal of Economics, v. 111, n. 1, p. 269-76, 1996. 
BOWLES, S.; BOYER, R. Wages, aggregate demand, and employment in an open economy: an empirical investigation. In: EPSTEIN, G.; GINTIS, H. (eds.) Macroeconomic policy after the conservative era. Cambridge: Cambridge University Press, p.143-71, 1995.

BRAGA, J.M. Investment rate, growth and the accelerator effect in the Supermultiplier model: the case of Brazil. Review of Keynesian Economics, v. 8 n. 3, p. 454-66, 2020.

BRUNO, M. Regimes de crescimento, mudança estrutural e distribuição na economia brasileira (1970-2001). Anais do VIII Encontro Nacional de Economia Política, 2003.

CESARATTO, S., SERRANO, F., STIRATI, A. Technical Change, Effective Demand and Employment. Review of Political Economy, v. 15, n. 1, p. 33-52, 2003.

DE LONG, J. B.; SUMMERS, L. Equipment Investment and Economic Growth. Quarterly Journal of Economics, v. 106, p. 445-502, 1991.

DE LONG, J. B.; SUMMERS, L. Equipment Investment and Economic Growth: How Strong is the Nexus. Brookings Papers on Economic Activity, p. 157-211, 1992.

EDERER, S. Competition-oriented wage policies and its effect on effective demand in the Netherlands. WIFO Working Papers, n. 321, 2008.

EDERER, S.; STOCKHAMMER, E. Wages and aggregate demand: an empirical investigation for France. In: HEIN, E.; TRUGER, A. (eds.) Money, Distribution and Economic Policy: Alternatives to Orthodox Macroeconomics. Edward Elgar, 2007.

FREITAS, F.; SERRANO, F. Growth rate and level effect, the adjustment of capacity to demand and the Sraffian Supermultiplier, Review of Political Economy, v. 27, n. 3, p. 258-81, 2015.

GIRARDI, D.; PARIBONI, R. Autonomous demand and the investment share, Review of Keynesian Economics, v. 8, n. 3, p. 428-53, 2020.

GORDON, D. Growth, distribution, and the rules of the game: social structuralist macro foundations for a democratic policy. In: EPSTEIN, G.; GINTIS, H. (eds.) Macroeconomic policy after the conservative era: studies in investment, saving and finance. Cambridge University Press, 1995.

GREGORY, A.; HANSEN, B. Tests for Cointegration in Models with Regime and Trend Shifts. Oxford Bulletin of Economics and Statistics, v. 58, n. 3, 1996.

HALUSKA, G; BRAGA, J.; SUMMA R. Growth, investment share and the stability of the Sraffian Supermultiplier model in the United States economy (1985-2017) Discussion Paper, IE-UFRJ, v. 24, 2020.

HARTWIG, J. Distribution and growth in demand and productivity in Switzerland (19502010), KOF Working Papers, KOF Swiss Economic Institute, n. 323, 2013.

HEIN, E. Distribution and Growth after Keynes: A Post Keynesian Guide, Cheltenham, Edward Elgar Publishing Limited, 2014.

HEIN, E.; VOGEL, L. Distribution and growth reconsidered: empirical results for six OECD countries. Cambridge Journal of Economics, v. 32, p. 479-511, 2008.

HEIN, E.; VOGEL, L. Distribution and growth in France and Germany - single equation estimations and model simulations based on the Bhaduri/Marglin - model, IMK Working Paper, n. 4, 2009. 
LAVOIE, M. Convergence Towards the Normal Rate of Capacity Utilization in Neo-Kaleckian Models: The Role of Non-Capacity Creating Autonomous Expenditures, Metroeconomica, v. 67, n. 1, p. 172-201, 2016.

LIPSEY, R.; KRAVIS, I. Saving and Economic Growth: Is the United States Really Falling Behind?, New York, The Conference Board, 1987.

MARQUETTI, A.; Porsse, M. Padrões de Progresso Técnico na Economia Brasileira: 19522008. Revista Cepal, 2014.

MIYAZAWA, K. Input-Output Analysis and the Structure of Income Distribution, New York: Springer-Verlag, 1976.

MOREIRA, V. G. Acelerador forte e concavidade na função consumo em modelos neo-Kaleckianos: rediscutindo o crescimento liderado pelos salários. Nova Economia, v. 29, n. 3, 2019.

NAASTEPAD, C. W. M.; STORM, S. OECD demand regimes (1960-2000). Journal of Post Keynesian Economics, v. 29, n.2, 2007.

ONARAN, O.; GALANIS, G. Is aggregate demand wage-led or profit-led? National and global effects. International Labour Office (ILO) Publications: Conditions of Work and Employment Series, n. 40, 2012.

ONARAN, O.; STOCKHAMMER, E. Do Profits Affect Investment and Employment? An Empirical Test Based On The Bhaduri-Marglin Model. Working Paper Series: Growth and Employment in Europe: Sustainability and Competitiveness, n. 44, 2004.

PARIBONI, R. Autonomous Demand and Capital Accumulation: Three Essays on Heterodox Growth Theory, unpublished Ph.D. Dissertation, Dip. Economia Politica e Estatistica, University of Siena, 2015.

SALA-I-MARTIN, X. I Just Ran Two Million Regressions, American Economic Review, Papers and Proceedings of the Hundred and Fourth Annual Meeting of the American Economic Association, v. 87, n. 2, p. 178-183, 1997.

SERRANO, F. Long Period Effective Demand and the Sraffian Supermultiplier, Contributions to Political Economy, v. 14, p. 67-90, 1995a.

SERRANO, F. The Sraffian Supermultiplier, Unpublished Ph.D. Dissertation, Cambridge University, Cambridge, 1995b.

Serrano, F.; Freitas, F. The Sraffian Supermultiplier as an alternative closure for heterodox growth theory. European Journal of Economics and Economic Policies: Intervention, v. 14, p. 7091, 2017.

SERRANO, F.; FREITAS, F.; BHERING, G. The trouble with Harrod: the fundamental instability of warranted rate in the light of the Sraffian Supermultiplier. Metroeconomica, v. 70, p. 263-287, 2019.

STOCKHAMMER, E.; HEIN, E.; GRAFL, L. Globalization and the effects of changes in income distribution on aggregate demand in Germany. International Review of Applied Economics, v. 25, n. 1, 2011.

STOCKHAMMER, E.; ONARAN, O. Accumulation, distribution and employment: a structural VAR approach to a Kaleckian macro model. Structural Change and Economic Dynamics, v. 15 , p. 421-447, 2004. 
STOCKHAMMER, E.; ONARAN O.; EDERER, S. Functional income distribution and aggregate demand in the Euro area. Cambridge Journal of Economics, v. 33, p. 139-159, 2009.

STOCKHAMMER, E.; STEHRER, R. Goodwin or Kalecki in Demand? Functional Income Distribution and Aggregate Demand in the Short Run. Review of Radical Political Economics, 2011.

UEMURA, H. Growth, distribution and structural change in the post-war Japanese. In: BOYER, R. e YAMADA, T. (eds.) Japanese Capitalism in Crisis: A Regulationist Interpretation, Advances in International Political Economy. Routledge, 2000.

\footnotetext{
About the authors

Joana David Avritzer-joanavritzer@gmail.com Instituto de Relações Internacionais e Defesa (IRID), Universidade Federal do Rio de Janeiro, Rio de Janeiro, RJ, Brazil. ORCID: https://orcid.org/0000-0002-7039-9198.

Fabio Neves Perácio de Freitas - fnpfreitas@gmail.com

Instituto de Economia (IE), Universidade Federal do Rio de Janeiro, Rio de Janeiro, RJ, Brazil. ORCID: https://orcid.org/0000-0001-8499-111X.

Julia De Medeiros Braga-jbraga@id.uff.br

Faculdade de Economia, Universidade Federal Fluminense, Niterói, RJ, Brazil. ORCID: https://orcid.org/0000-0002-7743-0725.

The authors would like to thank the two anonymous referees for the comments and contributions to the paper. This paper is the result of a masters' dissertation research developed with funding from Capes. Finally, the authors would like to thank the comments and contributions of professors Frederico Gonzaga Jayme Jr and Carlos Pinkusfeld Monteiro Bastos during the dissertation defense.
}

\section{About the article}

Submission received on August 09, 2019. Approved for publication on September 11, 2020. 